UDK 274 Luther, M. 27-312.8:2-12 https://doi.org/10.31337/oz.73.3.4 Pregledni rad Primljeno 23.8.2018. Prihvaćeno 25.10.2018.

\title{
Lutherova teologija križa
}

\author{
Lidija Matošević*, Tomislav Minić***
}

\begin{abstract}
Sažetak
Rad predstavlja osnovne crte teologije križa u teološkom opusu Martina Luthera (1483.-1546.). Polazi se od toga da teologija križa nije Lutherov teološki domišljaj, nego je Luther preuzima od ranije kršćanske tradicije i na sebi je svojstven način radikalizira. U radu se stoga ukazuje na začetke teologije križa u Novom zavjetu te posebice u Pavlovim spisima. Predstavljaju se pokreti u povijesti Crkve prije Luthera za koje je teologija križa bila bitna inspiracija i odrednica, pri čemu se posebnu važnost pridaje kasnosrednjovjekovnomu pokretu mistike patnje te kasnosrednjovjekovnomu pokretu devotio moderna. Potom se postavlja pitanje o Lutherovoj recepciji dotadašnje tradicije teologije križa, odnosno o njezinu značenju kod Luthera. Ukazuje se na Lutherovo suprotstavljanje teologije križa (theologia crucis) i tzv. teologije slave (theologia glorie), odnosno na Lutherovo razumijevanje teologije križa kao načela teološke epistemologije. Postavlja se pitanje o Lutherovoj dosljednosti u provedbi njegova programa teologije križa. Pritom se pažnja pridaje kritici Lutherove „poštede“ tradicionalne metafizike onako kako je ona artikulirana u djelu Jürgena Moltmanna.

Ključne riječi: Pavao (apostol), Martin Luther, teologija križa, teologija slave, predreformacijski reformni pokreti, Jürgen Moltmann
\end{abstract}

\section{Uvod}

Namjera je ovog članka prikazati u osnovnim crtama teologiju križa začetnika reformacije Martina Luthera s obzirom na pitanje njezine geneze i sadržaja. U prvom se dijelu rada prikazuje teologija križa u kršćanskoj tradiciji prije Luthera. Razmatranje otpočinje novozavjetnom, a posebice Pavlovom predajom, kako bi se zatim usredotočilo na kasnosrednjovjekovne pokrete koji su prethodili Lutheru i na njega utjecali. Među njima osobita važnost pripada pokretu mistike patnje, a djelimice i pokretu devotio moderna. $U$ drugom se dijelu rada razmatra geneza Lutherove teologije križa, i to ponajprije s obzirom na Lutherovu oslonjenost

* Izv. prof. dr. sc. Lidija Matošević, Sveučilišni centar za protestantsku teologiju Matija Vlačić Ilirik. Adresa: Ivana Lučića 1a, 10000 Zagreb, Hrvatska. E-pošta: lidija.matosevic@tfmvi.hr

** Tomislav Minić, student, Sveučilišni centar za protestantsku teologiju Matija Vlačić Ilirik. Adresa: Ivana Lučića 1a, 10000 Zagreb, Hrvatska. E-pošta: tminic@tfmvi.hr 
na kasnosrednjovjekovne tradicije, ali i na specifičnost te novost u artikulaciji dotadašnje tradicije. U tom se smislu posebna pažnja posvećuje ulozi Lutherovih duhovnih previranja. Potom se izlaže Lutherova teologija križa, odnosno njegovo razumijevanje teologije križa kao programskog načela teološke epistemologije te njegovo razlikovanje između teologije križa i teologije slave. Na kraju se propituje Lutherova dosljednost u provedbi njegova programa teologije križa.

\section{Teologija križa prije Luthera}

\subsection{Teologija križa u Novom zavjetu, odnosno u Pavlovim spisima}

Križ, odnosno Isusova smrt na križu, središnja je tema kršćanskog navještaja onako kako je on prenesen u Novom zavjetu. Po križu, odnosno u raspetom Kristu, dogodilo se spasenje koje Novi zavjet opisuje nizom izraza, kao što su otkupljenje (Gal 3,13), davanje života kao otkupnine (Mk 10,45), izbavljenje od pokvarenog svijeta (Gal 1,4), pomirenje (Rim 325; 2 Kor 5,19), zadobivanje vječnog života (Iv 3,16), umiranje zbog ljudskih grijeha, oslobađanje od grijeha te uvođenje u novost života (Rim 6,1-14 i 5,8; 1 Kor 15,3; 2 Kor 5,21) (Luz, 1974, 116-141). ${ }^{1}$

Ključni novozavjetni navodi koji su relevantni za elaboriranje Lutherove teologije križa nisu samo oni u kojima se pisci pozivaju na otkupiteljsko značenje Kristove smrti na križu, nego su to primarno mjesta u kojima je izravno riječ o teologiji križa, gdje se ne konstatira samo događanje oproštenja grijeha i otkupljenja ljudskog roda iz vlasti grijeha, nego se ističe da se na križu dogodila objava samoga Boga, koji je, upravo na križu, u poniznosti i patnji, odlučio progovoriti o tome tko je on ustvari.

U tom je smislu od ključne važnosti Pavlov tekst iz 1 Kor 1,21-24. »Doista, kad svijet u mudrosti Božjoj Boga ne upozna mudrošću, svidjelo se Bogu ludošću propovijedanja spasiti vjernike. Jer i Židovi znake ištu i Grci mudrost traže, a mi propovijedamo Krista raspetoga: Židovima sablazan, poganima ludost, pozvanima pak — i Židovima i Grcima — Krista, Božju snagu i Božju mudrost « (1 Kor 1,21-24).

Tu se dakle poručuje da se Bog — budući da ga čovjek svojim vlastitim snagama, odnosno svojom mudrošću nije uspio spoznati — odlučio objaviti na drugačiji način: u Isusu Kristu, odnosno u njegovoj patnji koja je kulminirala na križu. U tom se smislu taj tekst može paralelno čitati s Pavlovim tekstom:

»Otkriva se doista s neba gnjev Božji na svaku bezbožnost i nepravednost ljudi koji istinu sputavaju nepravednošću. Jer što se o Bogu može spoznati, očito im je: Bog im očitova. Uistinu, ono nevidljivo njegovo, vječna njegova moć i božanstvo, onamo od stvaranja svijeta, umom se po djelima razabire tako da nemaju isprike. Jer premda upoznaše Boga, ne iskazaše mu kao Bogu ni slavu ni zahvalnost, nego ishlapiše u mozganjima svojim te se pomrači bezumno srce njihovo. Gradeći se mudrima, po-

1 Opširnije o teologiji križa u Novom zavjetu u: Detwiler i Zumstein, 2002. 
ludješe i zamijeniše slavu neraspadljivog Boga likom, obličjem raspadljiva čovjeka, i pticâ, i četveronožaca, i gmazova« (Rim 1,18-23).

U tom je potonjem tekstu riječ o tome da ljudi, iako im se Bog zapravo objavio posredstvom stvorenog svijeta te unatoč tomu što im je spoznaja Boga putem promatranja stvorenja i čovjeka u načelu bila moguća, Boga ipak nisu spoznali, nego su štovanje besmrtnog Boga zamijenili štovanjem samog stvorenja te se njihova mudrost pretvorila u ludost. Stoga je Bog odlučio objaviti se u patnji i slabosti, odnosno na križu koji je »sablazan«i »ludost « (1 Kor 1,23). To je način koji čovjek istina nije očekivao, ali ujedno i jedini način koji je primjeren situaciji ljudske izgubljenosti. Stoga spoznati Boga te postati dionikom njegova spasenja može samo onaj čovjek koji je odustao od samouznošenja zbog svoje mudrosti ili moralne izvrsnosti, nego je, ne ignorirajući svoju stvarnu situaciju, dopustio Bogu da mu postane blizak upravo u patnjama, izgubljenosti, slabosti i ograničenjima u kojima se stvarno nalazi (Lioy, 2015, 115-118). U tom smislu govori Pavao: »Najradije ću se dakle još više hvaliti svojim slabostima da se nastani u meni snaga Kristova. Zato uživam u slabostima, uvredama, poteškoćama, progonstvima, tjeskobama poradi Krista. Jer kad sam slab, onda sam jak « (2 Kor 12,9b-10). ${ }^{2}$

Premda je Pavlov govor o teologiji križa smješten u konkretan kontekst korintske zajednice, u smislu da teologija križa predstavlja i kritiku načina na koji se vjernici u korintskoj zajednici ophode jedni prema drugima, u neslogama, razdorima, hvalisanju i nadimanju određenih pojedinaca prema drugim članovima zajednice (usp. 1 Kor 11,17-22), moguće je ipak reći da teologija križa kod Pavla nije u funkciji samo moralnog primjera, nego je načelne teološke naravi: Pavao upravo u Raspetom vidi pravi Kristov identitet. Upravo stoga on i ne želi naviještati ništa drugo »osim Isusa Krista, i to razapetoga« (1 Kor 22; usp. Dugandžić, 2015, 547). S time u skladu, opora riječ križa ostaje kod Pavla i trajni dio kršćanskog navještaja o Uskrslom Kristu te ne može iz tog navještaja biti odstranjena, stoga Pavao naglašava istovjetnost Raspetog i Uskrslog Krista (1 Kor 15,3-8). ${ }^{3}$ Konačno, Pavao naglašava kako su križ i patnja također zalog pouzdanja u uskrsnuće i novo Božje stvaranje (Rim 8,18-27).

\subsection{Teologija križa u crkvenim pokretima prije reformacije}

Premda pavlovska teologija križa nije isčeznula iz povijesti kršćanske teologije koje je uslijedilo, moguće je reći da u razdoblju stare Crkve te teologije srednjeg vijeka pojam teologije križa ne predstavlja neki zaseban i jasno artikuliran pojam koji bi označavao samu narav teologije te time polazište za govor o Bogu, nego je on prisutan tek sporadično i u naznakama (Korthaus, 2007, 3). Tako se primjerice Tertulijan, premda je tvrdio kako se srž kršćanske vjere sastoji u tome da je Bog patio i umro na križu (Tertulijan, 1972), ipak ograđuje od ideje da bi na križu patio sam Bog (Otac), tvrdeći kako je dovoljno reći da se patnja na kri-

2 O teologiji križa kod Pavla vidi u: Käsemann, 1970, 151-177; Gräbe, 2008, 140-142; Vidović, 1997, 55-71.

3 Vidi o tome u: Dugandžić, 2015, 541. 
žu odnosila samo na drugu božansku osobu, Sina (Tertulijan, 1948; Tertulijan, 1942). ${ }^{4}$ Slična je situacija i kod Atanazija, koji, raspravljajući s arijevcima i apolinarijevcima, ispovijeda vjeru u Raspetoga kao Boga te svako odbijanje u tom pogledu karakterizira kao herezu, no pritom ipak tvrdi kako je Krist patio ne u svojem božanstvu, nego u svojem ljudskom tijelu (Schaff i Wace, 1892). ${ }^{5}$

Ideja o Bogu koji nam postaje spoznatljiv i pristupačan u patnji dolazi do obuhvatnijeg izražaja tek u vrijeme koje je prethodilo reformaciji. U tom je smislu bila od osobite važnosti mistička tradicija. Tu je ponajprije riječ o tzv. mistici srca, odnosno mistici patnje, koja se pojavljuje sredinom 14. stoljeća te predstavlja svojevrsnu alternativu takozvanoj visokoj mistici i njezinu shvaćanju da se do spoznaje Boga i spasenjskog sjedinjenja duše s Bogom dopire putem filozofsko-teološke spekulacije te meditacije u kojoj se ljudski duh uzdiže k Bogu, a što je pak moguće jer se u samoj ljudskoj duši nalaze elementi božanskog. Među mistike tog usmjerenja spadaju: Bernard iz Clairvauxa (1090.-1153.), Bonaventura (1221.-1274.), Hugo od sv. Viktora (1096.-1141.), Gerson (1363.-1429.), Meister Eckhart (1260.1328.), Suso (1295.-1366.), Brigita Švedska (1303.-1373.) (Adam, 1992, 183-185; Matošević, 2007, 349-350). Za razliku od visoke mistike, mistika patnje polazi od shvaćanja da je put do sjedinjenja s Kristom popločen patnjama stvarne ljudske situacije te iskustvom tjeskobe zbog osjećaja napuštenosti od Boga. Stoga je sjedinjenje duše s Bogom/Kristom plod Božjeg djelovanja u čovjeku koji se nalazi u krajnjoj tjeskobi te se ne pokušava iz nje izdići (Adam, 1992, 184-185; Matošević, 2007, 350). Zbog polazišta u univerzalnom ljudskom iskustvu patnje kao mjestu čovjekova susreta s Bogom, mistika patnje predstavlja i svojevrsnu popularizaciju mistike u kasnom srednjem vijeku, pri čemu upravo laička pobožnost počinje zauzimati sve važniju ulogu (Oberman, 1992, 16). Jedan od najpopularnijih promotora mistike srca bio je Johannes Tauler (oko 1300.-1361.)

U nešto manjoj mjeri nego u mistici patnje, elementi teologije križa bili su prisutni i u kasnosrednjovjekovnom pokretu devotio moderna. Riječ je o pretežito laičkom religijskom, ali i društvenom i kulturnom pokretu, koji se pojavljuje u 14 . stoljeću u Nizozemskoj. Karakteristika je tog pokreta bilo nastojanje da se nadiđe skolastika te oslanjanje na Sveto pismo, pri čemu se osobitu važnost pridavalo nasljedovanju Krista koji nam je blizak upravo po patnji i iskušenjima. Njegovi su pripadnici živjeli u tzv. zajednicama Sestara zajedničkog života i Braće zajedničkog života. Pokret je osobito bio vezan uz ličnosti Geerta Grootea (1340.-1384.) i Tome Kempenca (1380.-1471.), koji je poznat po knjižici De imitatione Christi („Nasljeduj Krista“) (Kottje i Moeller, 2008, 219-220). ${ }^{6}$ U njoj se ističe važnost Isusova uzora poniznosti kao i suobličavanja s patećim Kristom, čime se čovjek može uzdići do sličnosti s Kristovom božanskom naravi (Toma Kempenac, 2014, 9-10).

4 Pritom se Tertulijan kao dokazom Božje nesposobnosti za patnju koristi riječima iz Psalma 22 koje Isus izgovara u smrtnom času. Prema Tertulijanu, taj krik pokazuje da je Bog napustio Isusa te da se patnja na križu nije odnosila na samog Boga, nego samo na Isusa čovjeka.

5 O raspravi na tu temu vidi u: Jüngel, 2013, 64-66.

6 Velik dio pripadnika tog pokreta poslije se i pridružio reformaciji. O odnosu između devotio moderna i reformacije vidi u: Hinz, 1997. 


\section{Geneza Lutherove teologije križa}

\subsection{Utjecaj mistike patnje te pokreta devotio moderna na Martina Luthera}

Premda se, na prvi pogled, mistika i reformacija mogu činiti kao pojmovi među kojima je vrlo malo zajedničkoga, mistika predstavlja jedan od kasnosrednjovjekovnih pokreta koji su utjecali na reformaciju, a posebice na Luthera (Matošević, 2007, 347-348). Poznato je tako da je Luther čitao spise pisaca tzv. visoke mistike: Bernarda von Clairvauxa, Bonaventure, Huga od sv. Viktora i Gersona (Adam, 1992, 183). U Lutherovu su opusu tako prepoznatljivi određeni termini karakteristični upravo za jezik mistike, puput primjerice termina antiperistasis iz Gersonova djela De mystica theologia, koji se pojavljuje kao sinonim za termine kojima Luther opisuje Božju objavu kao objavu sub contrario odnosno in abscondito (WA 56, 387.2-4; W 57, 199.6.) (Oberman, 1992, 150). Tragovi mistike naziru se i u Lutherovu razumijevanju opravdanja, pri čemu je pravednost po kojoj čovjek biva opravdan, a to je pravednost koja je extra nos, opisana jezikom bliskim mistici. Riječ je ponajprije o upotrebi mističkih termina raptus i amor extaticus. Premda je točno da su termini dobili u Lutherovu opusu novu funkciju, ipak ih nije moguće razumjeti bez uzimanja u obzir njihova izvornog mističkog karaktera (WA 3, 372.23-35; WA 5, 163.28) (Obermann, 1992, 150; Andresen i Ritter, 1998, 11; Oberman, 1967, 20-59).

Za genezu Luthera u reformatora daleko je važnije njegovo zanimanje za mistiku srca, odnosno za mistiku patnje, pri čemu je na Luthera utjecao i njegov dušobrižnik Johannes Staupitz (Adam, 1992, 185-186). Na Lutherovu putu zbližavanja s mistikom srca osobito je važna bila antispekulativna pobožnost mistika Taulera usmjerena na susret s Kristom u jednostavnosti i patnji svakodnevnog života. Zanimljivo je da je upravo Luther pripremio za tisak spis u kojem su bile sažete Taulerove misli i to najprije 1516., a zatim, u potpunijem obliku, godine 1518., ${ }^{7}$ pri čemu je u predgovoru naglasio kako, uz Bibliju i Augustina, taj spis spada među najvažnije spise za formiranje njegove teologije (WA 1, 378.21-23). ${ }^{8}$

Prilično je izvjesna i Lutherova bliskost s pokretom devotio moderna. Tako je poznato da je Martin Luther pohađao katedralnu školu u Magdeburgu (vjerojatno 1497./98.) te stanovao kod Braće zajedničkog života (Lohse, 2006, 30). Tako je Luther upravo u svojim formativnim godinama bio pod izravnim utjecajem jednog od najpobožnijih pokreta srednjeg vijeka, koji je putem spasenja smatrao upravo suobličavanje s Isusom patećim čovjekom. I Lutherovi rani spisi, tj. spisi iz razdoblja početka njegove predavačke djelatnosti, svjedoče o tome da je bio upoznat s pojedinim najčitanijim djelima pokreta devotio moderna, kao primjerice s tekstovima Gerarda Zerbolta van Zutphena (1367.-1398.) (Oberman, 2008, 96-98). ${ }^{9}$

7 Riječ je o djelu anonimnog autora poznatog kao Frankfurter. Potpuni naslov djela vidi u: Grell, 1817. To se djelo od 1519. pojavljuje pod naslovom Theologia deutch. O njegovoj važnosti za Lutherovu teologiju vidi u: Oberman, 1992, 15.

8 Opširnije o odnosu Luthera i mističkih tradicija vidi u: Leppin, 2016; Hamm, 2010, 200-250.

9 Više o odnosu Luthera i pokreta devotio moderna vidi u: Kekow, 1937; Oberman, 2008, 96-98; Walker, 1966. 


\subsection{Važnost Lutherovih osobnih duhovnih previranja na putu artikulacije njegove teologije križa}

Ne umanjujući važnost utjecaja kasnosrednjovjekovnih pokreta za artikulaciju Lutherove teologije, potrebno je svratiti pozornost na to da je u genezi Lutherove teologije bio važan i njegov duhovni put, a osobito njegova rana duhovna previranja. Ključno pitanje oko kojega su se ta previranja koncentrirala bilo je kako pronaći milostivog Boga, odnosno kako zadobiti sigurnost o opravdanosti, odnosno prihvaćenosti vlastita života u Božjim očima: sigurnost o tome da se cijeli životni napor pojedinca neće na nekom Posljednjem sudu pokazati nedostatnim i bezvrijednim. U svojim kasnijim tekstovima, Luther ta svoja ranija duševna stanja opisuje kao stanje duše koja osjeća da iz njezine tjeskobe nema bijega, nego sve postaje tužiteljem, pri čemu je duša prepuštena potresnim jecajima te je naširoko raspeta s Kristom. Osobito je poznat Lutherov autobiografski zapis o njegovim previranjima iz nekog trenutka života prije tzv. reformacijskog obrata, a koji se nalazi u zaključnom dijelu njegova spisa Resolutiones disputationum de indulgentiarum virtute, napisanog tijekom zime 1517./18. godine (WA 1, 557.33-558.15).

Premda je moguće reći da je intenzitet Lutherovih duševnih muka bio iznimno visok, njegova se previranja po samoj svojoj naravi ne razlikuju bitno od onih kod njegovih suvremenika. Naime, Lutheru suvremena dušobrižnička praksa ukazuje na to da je tjeskoba oko pitanja izvjesnosti spasenja u Lutherovo vrijeme bilo zapravo pitanje epohe (Lohse, 2006, 32-33). Ono po čemu se Luther razlikovao od svojih suvremenika bio je njegov odgovor na tjeskobu koju je s njima dijelio. Lutherov odgovor na ljudskomu biću inherentnu tjeskobu po pitanju posljednjih stvari bio je blizak onomu pokreta mistike patnje te pokreta devotio moderna. Mogao bi se sažeti na sljedeći način: umjesto iznalaženja različitih bijegova iz situcije tjeskobe, u toj situaciji treba izdržati jer Boga, koji jedini može razriješiti pitanje ljudskog postojanja i tjeskobe, moguće je susresti samo u patnji. Zato Luther kritizira svaki oblik bijega iz situacije patnje te svako posizanje za bilo kojim sredstvom za ublažavanje ljudskomu biću inherentne tjeskobe. Doduše, gore spomenuti poznati Lutherov autobiografski zapis - u kojem odzvanjaju riječi »tu nema bijega « ${ }^{10}$ — nalazi se uklopljen u spis u kojem Luther kritizira praksu prodaje indulgencija. Pritom indulgencije predstavljaju, za Luthera, upravo svojevrsni pokušaj bijega od stvarnosti, u kojem Crkva, koja prodaje indulgencije, zloupotrebljava ljudsku muku nudeći lažni izlaz i lažnu sigurnost, te pritom još i zarađuje. U tom je smislu moguće reći da se Lutherovo osobno duhovno traženje u samim svojim početcima preklopilo s prvim sporom između Luthera i njemu suvremene teologije i crkvene prakse. ${ }^{11}$ Potrebno je ipak napomenuti da tema indulgencija predstavlja samo mala vrata kroz koja je Luther ušao u

10 Spomenuti autobiografski zapis objavljen je u hrvatskom prijevodu u: Lohse, 2006, 32-33.

11 Kritikom prodaje indulgencija Luther se bavio 1517. u svojih 95 teza, koje su poznate i kao Rasprava doktora Martina Luthera o moći i djelotvornosti indulgencija, s kojima otpočinje Lutherova otvorena kritika njemu suvremene Crkve i teologije. Kritikom prodaje indulgencija bavi se i 
kritiku zdanja ondašnje Crkve te, usporedo s time, u proces vlastitog duhovnog nalaženja i, s time povezanog, formiranja reformacijske teologije. Jer ono što je Luther u konačnici kritizirao, odnosno pravac u kojem se profilirala njegova kritika ondašnje teologije i Crkve, bio je ne samo kritika prakse kupoprodaje indulgencija, nego svaki pokušaj da čovjek svoje spasenje postigne izdižući se iz vlastite patničke stvarnosti. Pritom je sasvim nebitno čini li pojedinac to kupnjom indulgencije ili pak posizanjem za nekim drugim načinom bijega od stvarnosti: kao što je primjerice samodokazivanje putem moralnih postignuća, pobožnosti, obrazovanja, zgrtanja imetka pa i putem samog teološkog rada. Upravo stoga tema kritike indulgencija nema centralno mjesto u Lutherovoj teologiji, nego predstavlja samo kariku u lancu njezina formiranja i artikuliranja. ${ }^{12} \mathrm{~A}$ tu je od ključne važnosti Lutherova teologija križa.

\subsection{Lutherova artikulacija teologije križa kao programskog načela teološke epistemologije}

U travnju 1518. godine Luther je u Heidelbergu, u kaptolu svojeg reda, održao javnu disputaciju. ${ }^{13}$ Heidelberška disputacija bila je za Luthera prigoda i poticaj da sustavnije promisli o svojim teološkim uvjerenjima te da ih pokuša artikulirati nadilazeći okvir osobnih previranja, ali i aktualnih crkveno-političkih, a djelimice i ekonomskih pitanja kakva je bilo pobudilo njegovo osporavanje opravdanosti teologije i prakse vezane uz trgovinu indulgencijama (Plathow, 2015, 16). Putovanje, koje se dobrim dijelom odvijalo pješačenjem od Wittenberga prema Heidelbergu, Luther je iskoristio za temeljitu pripremu. Pritom mu je od velike koristi bio razgovor s njegovim suputnikom i kodisputantom u Heidelbergu, Leonardom Beierom. ${ }^{14}$

Osnovnu strukturu Heidelberške disputacije čini četrdeset teza koje su praćene argumentacijama. Od toga je prvih dvadeset i osam teza teološkog karaktera, a drugih dvanaest teza filozofskoga. ${ }^{15}$ Heidelberške teze ne predstavljaju samo Lutherovu provokaciju njemu suvremenoj teologiji i crkvenoj praksi kakva je bila prisutna u njegovim tekstovima koji su kritizirali prodaju indulgencija, nego je tu riječ o sustavnoj kritici skolastičke teologije. Pritom pak te teze nadilaze i Lutherovu dotadašnju kritiku skolastičke teologije kakva je, primjerice, bila izražena u njegovu spisu Disputatio contra scholasticam theologiam, u kojem je on polemizirao protiv primjene Aristotelove filozofije u kršćanskoj teologiji (WA 1, 224228). Tomu je tako jer Luther u Heidelberškoj disputaciji ne ostaje ograničen na samu kritiku skolastičke teologije, nego toj teologiji suprotstavlja i alternativnu

Lutherov spis Propovijed o oprostu i milosti iz 1518., a posebno pak već spomenuti spis Resolutiones disputationum de indulgentiarum virtute, koji je nastao u zimi 1517./18.

12 Tako u Lutherovim spisima, počevši već od 1518., pitanje o indulgencijama ili posve iščezava ili zauzima relativno sporedno mjesto (Lohse, 1995, 122-123).

13 Vidi o tome u: Lohse, 2006, 46-47. Tekst Lutherove Heidelberške disputacije nalazi se u: WA 1, 353-374.

14 Vidi o tome u: Plathow, 2015, 12-13.

15 Filozofske su teze pritom slabije razrađene od onih teoloških. Vidi o tome u: Seebass, 1983, 82. 
teologiju, s drugačijom metodologijom od skolastičke. Tu pak teologiju Luther naziva teologijom križa (theologia crucis). Teološke teze koje je Luther postavio tijekom Heidelberške disputacije predstavljaju tako temeljni tekst za Lutherovu teologiju križa.

Premda se u svojoj teologiji križa Luther djelomice mogao nadovezati na mistiku patnje, na devotio moderna, kao i na vlastita duhovna traženja, teologija križa u Heidelberškoj disputaciji nadilazi okvire pitanja o vlastitom spasenju. Jer tu je riječ o načinu na koji je uopće moguće spoznati Boga, odnosno promišljati i progovarati o samoj njegovoj naravi. Utoliko je moguće reći da Lutherova teologija križa nadilazi okvire soteriologije ili reforme crkvenog života te postaje spoznajnoteoretski temelj čitavog zdanja kršćanske teologije. Ono što je Luther najavio u svojoj Heidelberškoj disputaciji bila je jedna sasvim drugačija teologija, s drugačijim sadržajem, metodom i ciljem od dotadašnje (srednjovjekovne) teologije. Pritom Luther skolastičku teologiju, koju kritizira te kojoj suprotstavlja teologiju križa, naziva teologijom slave (theologia gloriae). Teologija križa razlikuje se od teologije slave utoliko što ta posljednja nastoji uskladiti govor o Bogu kakav se objavio u križu Isusa Krista s filozofskim govorom o Bogu kao najvišem biću koje spoznajemo na temelju promatranja stvorenog svijeta, odnosno dane stvarnosti. S druge strane, teologija križa ishodištem i kriterijem kršćanske teologije smatra sam događaj Kristova križa te s time usklađuje sve druge izričaje o Bogu (Althaus, 1963, 34-35). U tom je smislu za Lutherovu teologiju križa moguće reći da je u njoj riječ o svojevrsnoj „revolucionarnoj teologiji“ (Welker, 2012, 135), a njezina se metodološka novost sastoji u tome što „raspeti Bog“ postaje načelom teološke epistemologije (Althaus, 1963, 34-35).

Dvadeset i osam teoloških teza u Heidelberškoj disputaciji moguće je podijeliti u nekoliko grupa. U tezama 1-12 ukazuje se na to da čovjek ne može postići spasenje vlastitim djelima, a u tezama 13-18 na to da to čovjeku nije moguće ni vlastitim htijenjem, odnosno vlastitom (slobodnom) voljom. Za artikulaciju pak Lutherove teologije križa osobito je važna grupa teza od 19-24. Naime, u okviru te grupe teza Luther izlazi iz okvira soteriologije te kreće prema artikulaciji teologije križa kao načela teološke epistemologije. On tako teologiju križa opisuje kao suštinu istinske teologije, nasuprot teologiji slave. U tom su smislu osobito važne teze 19 i 20. Tako u tezi 19 Luther kaže: »Ne zaslužuje biti nazvan teologom onaj koji nevidljivo biće Božje spoznaje i razumije preko njegovih djela« (WA 1, 361.32).

Luther se tu koristi terminom djela imajući u vidu kontekst poslanice Rimljanima 1,20, gdje je riječ o djelima stvaranja, odnosno o svijetu koji je Bog stvorio. Spoznaja Boga na temelju djela bila bi, prema tome, takva spoznaja gdje se čovjek nastoji uspeti do spoznaje Boga umujući o svijetu koji je Bog stvorio i pritom se zapravo zapliće u stvorenje, a u konačnici u samog sebe (koji je također stvorenje) te ne dosiže do spoznaje Boga, nego štovanje nevidljivog Boga izvrće u štovanje stvorenja i svoje vlastite „mudrosti“. Upravo se stoga njegova mudrost pokazuje kao ludost (Rim 1,20-23) (Althaus, 1963, 27-29). 
Nasuprot tomu, teolog križa spoznaje Boga iz patnje. U tom smislu Luther nastavlja u tezi 20: »Onaj [zaslužuje biti nazvan istinskim teologom] koji spoznaje ono što je od Božjeg bića vidljivo i okrenuto svijetu, kao što je učinjeno vidljivim u patnji i križu. «16 Pritom se referira na Prvu poslanicu Korinćanima 1,21-23, gdje križ predstavlja objavu Boga u Isusovu čovještvu, njegovoj patnji i smrti. Izrazom pak »ono što je okrenuto svijetu « (lat. posteriora) aludira se na tekst iz Izlaska 33,18-23 (Althaus, 1963, 27-28). Prema Lutheru je, dakle, u Kristu raspetom sva istinska teologija i sva spoznaja Boga (WA 1, 362.15-23).

Artikulacija teologije križa nastavlja se i u tezi 21, u kojoj Luther kaže kako Boga i nije moguće spoznati nigdje drugdje osim u patnji i križu: »Boga pronalazi samo u patnjama i križu. $\ll^{17}$

Premda Lutherova teologija križa predstavlja izlazak iz isključivo soteriološkog okvira, ona je — s jedne strane — ipak usko povezana sa soteriologijom. Jer nemogućnost istinske spoznaje Boga na temelju promatranja njegovih djela (pri čemu čovjek umjesto u spoznaji Boga završava u veličanju stvorenja te u samoveličanju) analogna je nemogućnosti spasenja vlastitim snagama o kojoj Luther govori u tezama 1-18. To posebno podvlače teze 24-28. Tako Luther u tezi 24, očito se nadovezujući na jezik mistike, govori o potrebi svojevrsnog mističkog poništenja (annihilatio), pri čemu čovjek zna da »Bog u njemu čini sve«. Naglašavanje važnosti Božje milosti još se jasnije potcrtava u tezama 25-28, koje govore o opravdanju grješnika prihvaćanjem Božje milosti vjerom. Utoliko je moguće reći da termin djela u Heidelberškoj disputaciji ima dvojaku primjenu. Jedna je primjena onda kada Luther govori o nedostatnosti spoznaje Boga na temelju promatranja „djela“ stvaranja, a druga je onda kada Luther govori o nemogućnosti da čovjek vlastitim djelima, to jest vlastitom moralnošću, pa čak i vlastitom religioznošću, dosegne do Boga i njegova spasenja. No, i „patnja“ za Luthera ima dvojaki smisao: spoznajni i soteriološki. S jedne strane, tu je riječ o tome da je Božju istinsku bit moguće spoznati samo posredstvom Kristova križa, odnosno posredstvom Božje objave u Kristovoj patnji. S druge pak strane, „patnja“ označava i ljudsku patnju. Zato što prema Lutheru Božje spasenje koje se objavljuje u patnji može susresti pa tako i spoznati samo čovjek koji i sam pati, odnosno samo čovjek koji ne bježi od vlastite patnje, nemoći i bijede. To osobito dolazi do izražaja u argumentaciji uz tezu 21, gdje Luther kaže: »Onaj pak koji sebe isprazni kroz patnju više ne čini djela, nego zna da Bog učinkuje i čini sve što je u njemu. Stoga mu je svejedno čini li Bog to ili ne. On se ne hvali ako čini dobra djela niti je uznemiren ako Bog ne čini dobra djela kroz njega. On zna da je dovoljno ako pati i ponizi se pred križem kako bi se tim više poništio « (WA 1, 362.31). ${ }^{18} \mathrm{U}$ tom bi se smislu moglo reći da teologija križa za Luthera predstavlja ne samo kriterij za

16 Latinski tekst teze 19 i 20 glasi: »Non ille digne Theologus dicitur, qui invisibilia Dei per ea, que facta sunt, intellecta conspicit« (WA 1,361.32). »Sed qui visibilia et posteriora Dei per passiones et crucem conspecta intelligit «(WA 1, 362.2).

17 Latinski tekst teze 21 glasi: »Deum non inveniri nisi in passionibus et cruce« (WA 1, 362.30).

18 Usp. također: WA 1, 362.26; 362.31; 363.35; 362.32. 
spoznaju Boga, nego postaje i okosnicom njegova nauka o opravdanju grješnika te njegova razumijevanja kršćanskog življenja. ${ }^{19}$

Pritom je važno naglasiti da spoznaja Boga na temelju njegovih djela nije, prema Lutheru, u načelu nemoguća. Štoviše, ona je bila prvotna mogućnost čovjeka i od te je mogućnosti još uvijek nešto preostalo. Tomu je tako jer čovjek i nakon pada u grijeh nosi u sebi pojam (notio) Boga koji je sam Bog u njega usadio. No zbog zahvaćenosti čovjeka i stvorenja grijehom, mogućnost spoznaje Boga na temelju promatranja stvorenja postala je bitno umanjenom te zapravo upitnom te se čovjek lako može naći u situaciji da, misleći da spoznaje i štuje Boga, zapravo zapada u idolopoklonstvo. Nastavno na to, Luther opisuje posljedice grijeha kao situaciju u kojoj čovjek igra s Bogom igru „slijepoga miša“ (njem. Blindekuh). ${ }^{20}$

Ipak, bez postojanja u čovjeku pojma o Bogu koji mu je usađen od istinskog Boga, ne bi bilo moguće objasniti ni samu činjenicu idolopoklonstva, odnosno činjenicu da čovjek lažnim božanstvima pripisuje upravo božanske kvalitete te ih tako štuje kao Boga, poistovjećujući tako Boga s konstruktom vlastitih želja (WA 56, 176.29; WA 19, 205.35; WA 56, 179.11).

Upravo stoga Bog se čovjeku odlučio objaviti u patnji — približivši se tako ljudskoj izgubljenosti. To je ujedno i razlog što Luther smatra potrebnim teologiju slave — premda je ne smatra načelno nemogućom — na radikalan način zamijeniti teologijom križa. On stoga kaže u tezi 24: »Ne treba ipak izbjegavati to loše znanje ni Zakon, ali se čovjek bez Teologije i najboljim križevima najgore koristi $\ll\left(\right.$ WA 1, 363.25). ${ }^{21}$

Tu je važno napomenuti kako, prema Lutheru, teologija križa, nije nužna samo zbog toga što je čovjek, budući da su čovjek i stvorenje zahvaćeni grijehom, ometen u svojoj mogućnosti da promatrajući stvoreni svijet doista spozna Boga. Kod Luthera je tako moguće naći izričaje prema kojima je istinska Božja narav u dubini svojeg otajstva spoznatljiva isključivo putem Božje objave na križu. Tako čovjek, promatrajući stvorenje, može u najidealnijem smislu spoznati da je Bog svemoćan, sveznajući, mudar, dobar i pravedan (WA 18, 709.10; 718.15; 709.20; WA 56, 177.3; WA 39 II, 346.1.11), no istinsku tajnu Božje naravi može spoznati samo putem Božje objave na križu (WA 1, 363.25). Zato što se upravo na križu Bog pokazuje onakvim kakav jest, tj. kao onaj koji pati, odnosno supati s čovjekom, a njegova se moć očituje u svojoj biti, tj. kao moć koja se očituje u tome da stvara ni iz čega i iz suprotnosti, odnosno kao moć Boga koji uskrisuje mrtve te opravdava grješnike (WA 40 I, 607.28). Štoviše, u križu je razotkrivena sama tajna unutarbožanskog života, a to znači otajstvo Trojstva (WA 45, 90.12; 91.5; WA 49, 238.6; 239.5), ${ }^{22}$ koje se upravo na križu otkriva kao Trojstvo sposobno za

19 Vidi o tome u: Althaus, 1963, 36-38.

20 »Die Vernunft weiss, dass Got ist. Aber wer oder welcher es sei, der da recht Gott heisst, das weiss sie nicht Š...Ć Die Vernunft spielt Blindekuh mit Gott «(WA 19, 206.32).

21 Latinski tekst glasi: »Non tamen sapientia illa mala nec Lex fugienda, sed homo sine Theologia crucis optimis pessime abutitur.« Vidi o tome i u: Althaus, 1963, 41.

22 Usp. Althaus, 1963, 30. Vidi o korelaciji teologije križa i nauka o Trojedinom Bogu kod Luthera u: Peters, 1985, 87; Jansen, 1976, 116. 
patnju, odnosno Trojstvo na koje utječe patnja stvorenja (WA 54, 91-92; WA 39 II, 120.21-22; 121.1-2,6-12). ${ }^{23}$ Budući da tako križ predstavlja put spoznaje dubine samog Božjeg bića, Luther upozorava na uzaludnost, a zapravo i na pogubnost traženja puta spoznaje Boga drugdje do u raspetom Kristu. Stoga mu je, premda ostavlja prostora za načelnu mogućnost spoznaje Boga na temelju promatranja stvorenja, moguće upotrijebiti i eksluzivistički izričaj kojim tvrdi mogućnost spoznaje Boga isključivo u Isusu Kristu, a također i reći da će svaki onaj koji Boga pokušava pronaći drugdje doli u patećem Kristu, umjesto Boga pronaći samoga vraga (WA 30 III, 213.34).

Kao radikalan preokret u spoznaji Boga, teologija križa predstavlja za Luthera također i radikalnu promjenu kriterija u razumijevanju cjelokupne stvarnosti. Iz perspektive teologije križa koja govori o Božjoj sposobnosti za patnju, a to znači i za promjenu, istinska stvarnost nije tako ono što ljudski razum i iskustvo percipira kao dano, kako bi na temelju promatranja toga danoga zaključivao o Bogu, nego je istinska stvarnost zapravo skrivena: u križu i patnji, odnosno u budućnosti koju stvara Bog. Ona je stoga spoznatljiva tek iz perspektive Kristova uskrsnuća. A to znači, u onom što se ljudskomu razumu i iskustvu može činiti ništavnim pa čak i nepostojećim, a dohvatljivo je vjeri koja se uzdaje u Božja obećanja te budućnost koja je skrivena u Bogu. Upravo će stoga, kao što Luther naglašava u argumentaciji uz tezu 28, vjernik biti bližnji onima koji nemaju izgleda, onima koji su grješni, odbačeni i slabi, onima koji trpe progone, nepravde i bijedu (WA 17 II, 203.15). ${ }^{24}$ Tako shvaćenu teologiju križa Luther je dalje zastupao u cijelom nizu svojih tekstova, među kojima se ističu „spisi utjehe“ (Trostschrifte), „pisma utjehe“ (Trostbriefe), „propovijedi utjehe“ (Trostpredigte) te „pjesme utjehe" (Trostliedern). ${ }^{25}$

Središnje značenje križa za razumijevanje Božje naravi i cjelokupne stvarnosti Luther je osobito snažno naglasio u spisu Operationes in Psalmos 1518./1519., u kojem je i sadržana njegova prodorna izreka Crux sola est nostra theologia (AWA 2, 309.3) i izreka Crux probat omnia (AWA 2, 325.1), koje označavaju upravo to da je jedina prava teologija ona kojoj je središte i polazište križ koji sve stavlja na kušnju te je jedini sudac i svjedok istine (Lohse, 1995, 51f; Plathow, 2014, 35-36). Utoliko je moguće reći da teologija križa predstavlja kako krizu shvaćanja Boga kao najvišeg bića, tako i krizu statične slike stvarnosti čije je polazište status quo (Plathow, 2014, 23).

Iako su te izjave nastale u razdoblju sukoba, to ne umanjuje njihovu programatsku važnost te složenost zadatka s kojim se Lutherova teologija slijedeći ih tek trebala suočiti.

23 Luther se pritom poziva na učenje o communicatio idiomatum te tako tvrdi kako je patnja čovjeka Isusa bila istovremeno i patnja Sina Božjeg, a time i patnja koja se ticala i najdubljeg otajstva Božjeg bića. Vidi o tome u: Plathow, 2014, 26. Kao takav, događaj križa, ima i povratni učinak na sam život Trojedinog Boga, odnosno imanentnog Trojstva (WA 7, 214-220; WA 12, 585-591; WA 11, 48-54; 450.27-451.20). Vidi o tome još u: Plathow, 2014, 34.

24 Vidi o tome u: Althaus, 1963, 40-41, 58-59.

25 O tim Lutherovim tekstovima vidi u: Plathow, 2015, 42-55. 


\subsection{Pitanje Lutherove dosljednosti u provedbi njegove teologije križa}

Lutherova teologija križa, sa svojim programom koji se sastojao u tome da govor o križu nadiđe okvire soteriologije te apela za crkvenom reformom, nosila je u sebi potencijal revolucionarne teologije (Welker, 2012, 135): u smislu teologije za koju Božja narav nije statična, nego je u dubini svojeg bića ganuta patnjom stvorenja te u kojoj se i cjelokupna stvarnost ne promatra kao takva koja naprosto jest, nego je razmišljanje o Bogu i njegovoj naravi u uskoj korelaciji s idejom o krizi postojećega. Upravo je stoga moguće reći kako u Lutherovoj teologiji križa nije bila riječ o nečemu što treba uskladiti s dotadašnjom teologijom i uklopiti u postojeći filozofsko-teološki sustav, koji je započinjao naukom o Bogu kao najvišem biću o kojem je moguće zaključivati promatrajući poredak u stvorenju, odnosno svijetu. Umjesto toga, Lutherova teologija križa imala je potencijal postati sustavna kritika pogleda na Boga i cjelokupnu stvarnost koja počiva na statusu quo, odnosno kritika pristupa stvarnosti čija se bit sastoji u odvraćanju pogleda od situacije patnje: kako ljudske tako i božanske (Matošević, 2014, 64).

Tu se nameće pitanje u kojoj je mjeri Lutherova teologija dosljedno provela kritiku statičnog poimanja Boga i svijeta, odnosno odnosa između Boga i svijeta kakav je bio zastupljen u aristotelovoj metafizici, odnosno u teologiji koja je nju bila u sebe uklopila.

Kako bismo odgovorili na to pitanje, potrebno je još jednom svratiti pozornost na temeljni tekst u kojem Luther iznosi svoju teologiju križa: Heidelberšku disputaciju. Ono što proizlazi iz tog teksta jest da Luther, unatoč svoj odlučnosti u tvrđenju kako je dubinu Božjeg bića, a time i cjelokupnu stvarnost, moguće spoznati jedino putem križa te kako križ predstavlja korektiv i kritiku svih drugih nastojanja za spoznajom Boga i stvarnosti, još uvijek na neki način ostavlja netaknutom sliku Boga i svijeta koja stoji iza tradicionalne metafizike, premda ju $\mathrm{u}$ isto vrijeme kritizira. Naime, težište Lutherove kritike tzv. teologije slave nije bilo u kritici teologije slave kao takve, odnosno tradicionalne metafizike koja se nalazi u njezinu temelju, nego u tome što, prema Lutheru, put teologije slave čovjeka, koji je bitno određen svojom grješnošću, lako može dovesti u iskušenje da veliča vlastito znanje, odnosno vlastita postignuća. U tom bi se smislu moglo reći da Lutherova kritika nije bila upućena toliko samoj teologiji slave, nego čovjeku koji se njome pokušava baviti: teologu slave. Jer za Luthera spoznaja koja spašava nije spoznaja najvišeg bića i ljudske izvrsnosti koja je sposobna spoznati nešto o tom biću, nego spoznaja raspetog Krista i ljudske grješnosti. Iz Lutherovih tekstova proizlazi također i to da teologija križa ne isključuje načelno tradicionalnu metafiziku i teologiju koja je u nju uklopljena niti dovodi u pitanje njezinu logiku i opstanak. Štoviše, teolog gloriae i teolog crucis, budući da se, zapravo, i ne bave istom problematikom - jer jednomu je ponajprije do znanja, a drugomu ponajprije do spasenja - ne mogu doći u sukob. U tom su smislu vrijedni pažnje Lutherovi izričaji u samoj Heidelberškoj disputaciji, u kojima on savjetuje teologa, odnosno kršćanina, da se teologijom slave ne bavi i to ne ponajprije zato što ona nije istinita, nego zato što ona, za čovjeka, odnosno za čovječanstvo, koje 
je zahvaćeno grijehom te pati od njegovih posljedica, nije spasonosna (WA 1, $363.25){ }^{26}$

Pitanje koje se nameće na tom mjestu jest sljedeće: Može li se križ učiniti načelom teološke epistemologije a pritom ostaviti netaknutom tradicionalnu metafiziku i na njoj sazdanu teologiju te je li dovoljno kritizirati samo teologa slave?

Prije nego što se odgovori na to pitanje potrebno je napomenuti da je Lutherova teologija križa u protestantskoj teologiji narednih stoljeća postala zaboravljenom temom. Tako je za dugo vrijeme u barem djelomičan zaborav potonuo i sam ključan tekst za teologiju križa: Heidelberška disputacija. Veći interes za tu temu i tekst javlja se tek u prvoj polovici 20. stoljeća, a osobito nakon suočavanja s iskustvom tragedije konflikata i svjetskih ratova. ${ }^{27}$ Tako se na važnost Lutherove teologije križa iznova ukazuje u radovima Karla Bauera (1901), Paula Althausa (1929, 1-50), Ericha Vogelsanga (1932), Walthera von Loewenicha (1929), Hansa Joachima Iwanda (2000). ${ }^{28}$ Te je radove, počevši od druge polovice 20. stoljeća, slijedio velik broj drugih radova koji su predstavljali svojevrsnu renesansu Lutherove teologije križa. ${ }^{29}$ Osobitost je tih radova da se u njima ukazuje na potencijal koji je sadržan u Lutherovoj teologiji križa kao sveobuhvatnoj teologiji koja unosi revoluciju u razumijevanje cjelokupne stvarnosti, ali se nerijetko ukazuje i na Lutherovu manjkavu dosljednost u provedbi njegova teološkog programa.

Pritom se vrlo često upravo Lutherova ,pošteda“ tradicionalne metafizike od radikalnije kritike s pozicije teologije križa, a time i neminovno svođenje teologije križa na svojevrsnu teologiju pobožnosti, ocjenjuje kao slaba točka njegove teologije.

Jedna od najupečatljivijih renesansi, ali i kritika Lutherove teologije križa u vezi s njezinom dosljednosti, dogodila se u okviru teologije Jürgena Moltmanna. Prema Moltmannu theologia crucis i theologia gloriae jedna drugu neumitno dovode u pitanje. Tomu je tako jer teologija križa govori u konačnici o tome što križ znači za Boga samoga, a time i za cjelokupnu stvarnost te, polazeći odatle, i za naše spasenje. Ona stoga ne može biti ograničena na područje soteriologije. Središnje pitanje koje u vezi s teologijom križa postavlja Moltmannova teologija i jest pitanje o tome što križ znači za Boga samoga, odnosno za život imanentnog Trojstva. ${ }^{30}$ Prema Moltmannovu konceptu, koji je poznat i kao trinitarna teologija križa, križ i ono što se na križu dogodilo postalo je konstitutivnim za osobe Božanskog Trojstva te njihove međusobne odnose, a to znači za samu Božju narav. Prema Moltmannu, upravo je oskudna dorečenost teologije križa u tom pogledu najozbiljniji problem Lutherove teologije. Jer u Lutherovoj je teologiji, prema Moltmannu, u konačnici ipak riječ o tome da se — pozivajući se na nauk o dvije naravi u Kristu te s time povezano učenje o communicatio idiomatum -

26 Vidi o tome u: Althaus, 1963, 41-43.

27 Premda i u 19. stoljeću postoji interes za Heidelberšku disputaciju kao povijesni događaj, interes za sam njezin sadržaj budi se iznova zapravo tek u 20. stoljeću (Plathow, 2015, 19).

28 Riječ je i o razdoblju tzv. Lutherove renesanse (Helmer i Holm, 2015, 40-43).

29 Ovo su samo neki od brojnih radova: Blaumeiser, 1995; Bornkamm, 1975; Bühler, 1981; Dalferth, 1997, 57-85; Kitamori, 1972; Korthaus, 2007; McGrath, 1985; Plathow, 2015.

30 To se pitanje provlači ponajviše u Moltmannovim knjigama $(1972 ; 1980)$. 
ustuknulo pred pravim skandalom koji u sebi nosi teologija križa, a to je da je Sin napušten od Oca, da se ta bogonapuštenost Sina događa u Duhu te da je time sama narav Trojedinog Boga aficirana Isusovom patnjom na križu. U tom smislu križ Isusa Krista uvodi radikalnu promjenu, štoviše revoluciju u samom konceptu Boga te postaje konstitutivnim za razumijevanje same Božje naravi, koja se, sa stajališta teologije križa, više nikako ne može promatrati kao narav nesposobna za patnju, a to znači i za promjenu (Moltmann, 1972, 184; 214; 222).

Dosljedno provedena teologija križa u smislu trinitarne teologije križa, prema Moltmannu, vodi i promjeni razmišljanja o cjelokupnoj stvarnosti. Jer trinitarna teologija križa nije kompatibilna s modelom u kojem se svijet pomatra kao analogan Bogu, nego je tu riječ o tome da se o cjelokupnoj stvarnosti razmišlja kao takvoj koja je uključena u Božju budućnost, odnosno u budućnost Boga koji u sebe preuzima patnju stvorenja kako bi stvorenje preobrazio te uveo u svoj počinak. To ne znači da soteriološko značenje križa kao okajanja za grijehe gubi kod Moltmanna na značenju, nego je pak riječ o tome da se u soteriologiji ne iscrpljuje punina događaja križa (Moltmann, 1972, 243-244).

\section{Zaključak}

Lutherova teologija križa predstavlja Lutherovu artikulaciju, odnosno reartikulaciju pobožnosti i teologije usredotočene na temu križa te božanske i ljudske patnje u vremenima koja su prethodila reformaciji. Među važnijim idejama tih pokreta bila je ona koja kaže da se istinski te spasonosni susret između čovjeka i Boga događa u samom središtu ljudske patničke egzistencije. Za Luthera je u tom pogledu od osobite važnosti bio njegov doticaj s kasnosrednjovjekovnim pokretom mistike patnje, kao i s elementima teologije križa prisutnima u kasnosrednjovjekovnom pokretu devotio moderna. Od osobite važnosti za formiranje teologije križa bila su Lutherova duhovna previranja usredotočena na pitanje kako pronaći milostivog Boga, pri čemu se Luther opirao svakomu obliku bijega iz situacije duševne patnje te kritizirao svaki pokušaj izdizanja iz vlastite patničke stvarnosti.

Ključan moment za artikuliranje Lutherove teologije križa predstavlja Heidelberška disputacija, u kojoj Luther teologiju križa kvalificira kao alternativu cjelokupnomu zdanju tadašnje skolastičke teologije, koju naziva teologijom slave (theologia gloriae).

U tom bi se smislu moglo reći da u Heidelberškoj disputaciji nije riječ samo o pitanju spasenja i milosti, nego i o načinu na koji je uopće moguće promišljati o samoj Božjoj naravi koja nije statična, nego je, u dubini svojeg bića, aficirana patnjom stvorenja. Stoga, prema Lutheru, teologija koja križ postavlja u središte određuje i promišljanje o samom imanentnom Trojstvu. U tom je pogledu moguće reći da je namjera Lutherove teologije križa bila križ učiniti spoznajnoteorijskim temeljem čitavog zdanja kršćanske teologije, pri čemu objava Boga na križu postaje kritikom i korektivom svih drugih puteva spoznaje Boga te time načelom teološke epistemologije različite od one u tzv. teologiji slave, čiji je temeljni problem što ona govor o Bogu kakav se objavio u križu Isusa Krista nastoji 
uklopiti u filozofski govor o Bogu kao najvišem biću koje spoznajemo na temelju promatranja dane stvarnosti.

Kao radikalan preokret u spoznaji Božje naravi kao takve koja nije statična, nego je, u dubini svojeg bića, ganuta patnjom stvorenja, a to znači i naravi koja je sposobna za promjenu, teologija križa prema Lutheru označava i radikalnu promjenu kriterija u razumijevanju cjelokupne stvarnosti kao takve, koja je zapravo skrivena u križu i patnji, odnosno u budućnosti koju stvara Bog. Istinska je stvarnost stoga spoznatljiva tek iz perspektive uskrsnuća te je dohvatljiva onomu koji vjeruje te kao takav postaje bližnji onima koji nemaju izgleda, koji su grješni, odbačeni i slabi. U tom smislu teologija križa predstavlja preobrazbeni potencijal sveukupne stvarnosti, odnosno krizu svake slike stvarnosti u čijem se temelju nalazi status quo.

Unatoč svoj odlučnosti u tvrđenju kako križ predstavlja korektiv i kritiku svih drugih nastojanja za spoznajom Boga i stvarnosti, Luther još uvijek ostavlja netaknutom sliku Boga i svijeta koja stoji iza tradicionalne metafizike. U tom su smislu od osobite važnosti Lutherovi izričaji iz kojih proizlazi kako njegova kritika nije upućena ponajprije teologiji slave zbog njezine neistinitosti, nego zato što takva teologija ne vodi spasenju i to utoliko što put teologije slave čovjeka koji je bitno određen svojom grješnošću lako može dovesti u iskušenje da on veliča vlastito znanje, odnosno vlastita moralna postignuća. U tom je smislu moguće reći da Lutherova kritika nije upućena toliko samoj teologiji slave, nego čovjeku koji se njome pokušava baviti te da ona ne isključuje načelno tradicionalnu metafiziku i teologiju koja je u nju uklopljena.

Upravo Lutherova „pošteda“ tradicionalne metafizike od radikalnije kritike s pozicije teologije križa, a time i neminovno svođenje teologije križa na reformu osobne pobožnosti te eventualno reformu Crkve, mogla bi se ocijeniti kao slaba točka njegove teologije. U tom pogledu jednu od najupečatljivijih renesansi, ali $\mathrm{u}$ isto vrijeme i kritiku Lutherove teologije križa u vezi s njezinom dosljednosti predstavlja teologija Jürgena Moltmanna. Ključni moment u Moltmannovoj recepciji Lutherove teologije križa predstavlja ukazivanje na potrebu radikalnije integracije teologije križa u sam nauk o Trojedinom Bogu, pri čemu je centralno pitanje koje treba postaviti ono o tome što križ znači za život imanentnog Trojstva. Prema Moltmannovu konceptu, koji je poznat i kao trinitarna teologija križa, križ i ono što se na križu dogodilo postalo je konstitutivnim za osobe božanskog Trojstva te njihove međusobne odnose, a to znači za samu Božju narav. Upravo oskudna dorečenost teologije križa u tom pogledu najozbiljniji je problem Lutherove teologije, koja je, pozivajući se na nauk o dvije naravi u Kristu te s time povezano učenje o communicatio idiomatum, ustuknula pred pravim skandalom koji u sebi nosi teologija križa: da je na križu Sin napušten od Oca, da se ta bogonapuštenost Sina događa u Duhu te da je time sama narav Trojedinog Boga aficirana Isusovom patnjom na križu. U tom smislu križ Isusa Krista uvodi revoluciju u samom konceptu Boga, ali i promjenu promišljanja o cjelokupnoj stvarnosti kao takvoj koja je uključena u budućnost Boga, koji u sebe preuzima patnju stvorenja kako bi stvorenje preobrazio te uveo u svoj počinak. 


\section{Literatura:}

Adam, Alfred (1992). Lehrbuch der Dogmengeschichte: Band 2: Mittelalter und Reformationszeit. Gütersloh: Gütersloher Verlagshaus Mohn.

Althaus, Paul (1929). Theologische Aufsätze. Gütersloh: Bertelsmann.

Althaus, Paul (1963). Die Theologie Martin Luthers. Gütersloh: Gütersloher Verlagshaus.

Andresen, Carl; Ritter, Adolf Martin (ur.) (1998). Handbuch der Dogmengeschichte und Theologiegeschichte: Band 2: Die Lehrentwicklung im Rahmen der Konfessionalität. Göttingen: Vandenhoeck \& Ruprecht.

AWA $=$ Gerhard Hammer (ur.), Martin Luther: Operationes in Psalmos. Archiv zur Weimarer Ausgabe der Werke Martin Luthers, Bd 2. Köln: Böhlau, 1981.

Bauer, Karl (1901). Die Heidelberger Disputation Luthers. Zeitschrift für Kirchengeschichte, 21, 233-268; 299-329.

Biblija. Kršćanska sadašnjost. URL: http://biblija.ks.hr/ (30.06.2018.)

Blaumeiser, Hubertus (1995). Martin Luthers Kreuzestheologie: Schlüssel zu seiner Deutung von Mensch und Wirklichkeit: Eine Untersuchung anhand der Operationes in Psalmos (1519-1521). Paderborn: Bonifatius.

Bornkamm, Heinrich (1975). Die theologischen Thesen Luthers bei der Heidelberger Disputation 1518 und seine theologia crucis. U: Heinrich Bornkamm, Luther: Gestalt und Wirkungen: Gesammelte Aufsätze (str. 130-146). Gütersloh: G. Mohn.

Bühler, Pierre (1981). Kreuz Und Eschatologie: Eine Auseinandersetzung Mit Der Politischen Theologie, Im Anschluss an Luthers Theologia Crucis (Hermeneutische Untersuchungen Zur Theologie). Tübingen: Mohr Siebeck.

Dalferth, Ingolf U. (1997). Gedeutete Gegenwart: Zur Wahrnehmung Gottes in den Erfahrungen der Zeit. Tübingen: Mohr Siebeck.

Dettwiler, Andréas; Zumstein, Jean (2002). Kreuzestheologie im Neuen Testament. Tübingen: Mohr Siebeck.

Dugandžić, Ivan (2015). Mesijanizam u svjetlu Pavlove teologije križa (1 Kor 1,13; 2,2; 2 Kor 4,4-5; Rim 1,3-4). Bogoslovska smotra, 85(2), 539-555.

Gräbe, Petrus J. (2008). The Power of God in Paul's Letters. Tübingen: Mohr Siebeck.

Grell, Karl (ur.) (1817). Die deutsche Theologie: das ist ein edles Büchlein vom rechten Verstand, was Adam und Christus sei, und wie Adam in uns sterben und Christus erstehen soll. Berlin: De Gruyter.

Hamm, Berndt (2010). Der frühe Luther. Tübingen: Mohr Siebeck.

Helmer, Christine; Holm, Bo Kristian (ur.) (2015). Lutherrenaissance Past and Present. Göttingen: Vandenhoeck \& Ruprecht.

Hinz, Ulrich (1997). Die Brüder vom gemeinsamen Leben im Jahrhundert der Reformation: Das Münstersche Kolloquium. Tübingen: Mohr Siebeck.

Iwand, Hans Joachim (2000). Theologia crucis. U: Nachgelassene Werke. Bd. 2 (str. 381398). München: Kaiser.

Jansen, Reiner (1976). Studien zu Luthers Trinitätslehre. Frankfurt/M: Lang.

Jüngel, Eberhard (2010). Gott als Geheimniss der Welt: Zur Begründung der Theologie des Gekreuzigten im Streit zwischen Theismus und Atheismus. Tübingen: Mohr Siebeck.

Jüngel, Eberhard (2013). God as the Mistery of the World: On the Foundation of the Theology of the Crucified One in the Dispute between Theism and Atheism. Grand Rapids: Eerdmans.

Käsemann, Ernst (1970). The Pauline Theology of the Cross: Interpretation. A Journal of Bible and Theology, 2, 151-177.

Kekow, Rudolf (1937). Luther und die Devotio Moderna. Hamburg: G. H. Nolte. 
Kitamori, Kazo (1972). Theologie des Schmerzes Gottes. Göttingen: Vandenhoeck \& Ruprecht.

Korthaus, Michael (2007). Kreuzestheologie.Geschichte und Gehalt eines Programmbegriffs in der evangelischen Theologie. Tübingen: Mohr Siebeck.

Kottje Raymnud; Bernd Moeller (2008). Ekumenska povijest Crkve 2. Zagreb: Teološki fakultet "Matija Vlačić Ilirik".

Leppin, Volker (2016). Die fremde Reformation: Luthers mystische Wurzeln. München: C. H. Beck

Lioy, Dan (2015). Paul's Theology of the Cross: A Case Study Analysis of 2 Corinthians 11:16-12:10. Conspectus, 20, 89-133.

Loewenich, Walther von (1929). Luthers theologia crucis. München: C. Kaiser.

Lohse, Bernard (1995). Luthers Theologie in ihrer historischen Entwicklung und in ihrem systematischen Zusammenhang. Göttingen: Vandenhoeck \& Ruprecht.

Lohse, Bernhard (2006). Martin Luther: Život i djelo. Zagreb: Teološki fakultet "Matija Vlačić Ilirik".

Luz, Ulrich (1974). Theologia crucis als Mitte der Theologie im Neuen Testament. Evangelische Theologie, 34, 116-141.

Matošević, Lidija (2007). Protestantizam i mistika: Odnos Luthera i mističkih tradicija. U: Jure Zečević (ur.), The experience od God today and Carmelite mysticism: Mystagogy and Inter-Religious and Cultural Dialog (str. 347-362). Zidine: Karmelska KIZ Izdanja.

Matošević, Lidija (2014). Crux sola est nostra theologia — Isus iz Nazareta u reformacijskoj teologiji Martina Luthera. Nova prisutnost, 1, 49-64.

McGrath, Allister Edgar (1985). Luther's Theology of the Cross: Martin Luther's Theological Breakthrough. Oxford: Basil Blackwell.

Moltmann, Jürgen (1972). Der gekreuzigte Gott — Das Kreuz Christi als Grund und Kritik christlicher Theologie. München: Kaiser Verlag.

Moltmann, Jürgen (1980). Trinität und Reich Gottes: Zur Gotteslehre. München: Kaiser Verlag.

Oberman, Heiko Augustinus (1967). Simul gemitus simul raptus: Luther und die Mystik, Heiligung und das Naturrecht. U: Ivar Asheim (ur.), Kirche, Mystik, Heiligung und das Natürliche bei Luther (str. 20-59). Göttingen: Vandenhoeck \& Ruprecht.

Oberman, Heiko Augustinus (1992). The Dawn of the Reformation: Essays in Late Medieval and Early Reformation Thought. Michigan: Eerdmans.

Oberman, Heiko Augustinus (2008). Luther: A Man between God and the Devil. New Haven, CT: Yale University Press.

Peters, Albrecht (1985). Verborgener Gott — Dreieiniger Gott: Beobachtungen und Überlegungen zum Gottesverständnis Martin Luthers. U: Peter Manns (ur.). Martin Luther "Reformator und Vater im Glauben" (str. 74-105). Wiesbaden: Franz Steiner Verlag.

Plathow, Michael (2014). Vor Gott in der Welt: Luthers neues Wirklichkeitsverständnis. Berlin: Lit Verlag.

Plathow, Michael (2015). Das "Wort vom Kreuz" und die Kreuzestheologien: Luthers "Heidelberger Disputation" (April 1518) - fürs Heute neu bedacht. Berlin: Lit Verlag.

Schaff, Philip; Wace, Henry (1892). Athanasius — Four Discourses Against the Arians. Translated by John Henry Newman and Archibald Robertson. From Nicene and Post-Nicene Fathers, Second Series, Vol. 4. Buffalo, NY: Christian Literature Publishing Co. Revised and edited for New Advent by Kevin Knight. URL: http://www. newadvent.org/fathers/2816.htm (30.06.2018.)

Seebass, Gottfried (1983). Die Heidelberger Disputation. Heidelberger Jahrbücher, 27, $77-88$. 
Tertulijan (1948). Against Praxeas. Preveo s latinskoga na engleski Ernest Evans. URL: http://www.tertullian.org/articles/evans_praxeas_eng.htm (30.06.2018.)

Tertulijan (1972). Adversus Marcionem. Preveo s latinskoga na engleski Ernest Evans. URL: http://www.tertullian.org/articles/evans_marc/evans_marc_00index.htm (30.06.2018.)

Toma Kempenac (2014). Nasljeduj Krista. Priredio Ivo Blažević. Split: Verbum.

Vidović, Marinko (1997). Pavlova teologija križa u 1 Kor. U: Marin Škarica i Ante Mateljan (ur.), U križu je spas: Zbornik u čast nadbiskupa metropolita mons. Ante Jurića (str. 55-71). Split: Crkva u svijetu - Teologija u Splitu.

Vogelsang, Erich (1932). Der Angefochtene Christus bei Luther. Berlin — Leipzig: de Gruyter.

WA = Martin Luther, D. Martin Luther's Werke: Kritische Gesamtausgabe. Weimar: Heidelberger Akademie der Wissenschaften, 1883-2009.

Walker, James D. (1966). The Effect of the Devotio Moderna in the Formation of Martin Luther's Doctrine. New York: Niagara University Press.

Welker, Michael (2012). Gottes Offenbarung: Christologie. Neukirchen-Vluyn: Neukirchener Theologie.

\section{Luther's Theology of the Cross}

\section{Lidija Matošević*, Tomislav Minić**}

\section{Summary}

The article presents a basic outline of the theology of the cross in the theological works of Martin Luther (1483-1546). We commence with the fact that the theology of the cross is not Luther's theological invention, but rather that he adopted it from earlier Christian tradition and, in his own particular way, radicalized it. The article therefore brings to our attention the beginnings of the theology of the cross in the New Testament, particularly in Paul's writings. Various movements in the history of the Church before Luther are portrayed for which the theology of the cross was an important inspiration and determinant. Special emphasis is placed on a movement of the late medieval period, namely, the mysticism of suffering and also the late medieval movement devotio moderna. Furthermore, the issue is raised of Luther's reception of the tradition of the theology of the cross up until his time, or rather of its significance to Luther. The authors point out Luther's opposition to the theology of the cross (theologia crucis) and the so-called theology of glory (theologia glorie), that is to say, Luther's grasp of the theology of the cross as a principle of theological epistemology. Luther's consistency in implementing his program of the theology of the cross is questioned, and accordingly, attention is drawn to Luther's „insufficient criticality“ of traditional metaphysics such as it is articulated in the work of Jürgen Moltmann.

Key words: Paul (the Apostle), Martin Luther, theology of the cross, theology of glory, pre-Reformation reform movements, Jürgen Moltmann

* Lidija Matošević, Ph.D., Associate Professor, University Centre for Protestant Theology Matija Vlačić Ilirik. Address: Ivana Lučića 1a, 10000 Zagreb, Croatia. E-mail: lidija.matosevic@tfmvi.hr

** Tomislav Minić, Student, University Centre for Protestant Theology Matija Vlačić Ilirik. Address: Ivana Lučića 1a, 10000 Zagreb, Croatia. E-mail: tminic@tfmvi.hr 